УДК 339.56; 339.972

ББК 65.5

ТЕНДЕНЦИИ РАЗВИТИЯ ТЕХНОЛОГИЧЕСКИХ ТРАНСФЕРТОВ В ЕАЭС*

\author{
В. А. КЛИМЕНКО \\ vak_@tut.by \\ доктор социологических наук, профессор, \\ консультант Исполнительного комитета СНГ. \\ В. Л. ГУРСКИЙ \\ vhurski@yandex.ru
}

кандидат экономических наук, доцент, зав. кафедрой экономики

БИП-Институт правоведения

Минск, Республика Беларусь

Статья посвящена исследованию тенденщий развития технологических трансферов в ЕАЭС. Установлень и раскрыты тенденции развития технологических трансферов в ЕАЭС. Сделан вывод о преобладании положительных тенденций в развитии технологических трансфертов в ЕАЭС.

Ключевые слова: экономический рост, технологии, технологические трансферты, инновации, интересы, ЕАЭС

\title{
TRENDS IN THE DEVELOPMENT OF TECHNOLOGICAL TRANSFERS IN EAEU
}

\section{A. KLIMENKO}

Doctor of sociology, professor, consultant of the CIS Executive Committee

$$
\text { V. L. HURSKY }
$$

$\mathrm{PhD}$ in Economics, associate Professor, Head of the Department of Economics

BIP-Institute of law

Minsk, Republic of Belarus

The article is devoted to tendencies of development of technological transfer to the $E A E U$. Installed and revealed trends in the development of technological transfer to the EAEU. The conclusion is about the predominance of positive trends in development of technological transfer to the EAEU.

Keywords: economic growth, technologies, technological transfers, innovations, interests, EAEU.

\section{ВВЕДЕНИЕ}

Сегодня экономическое развитие стран мира во многом определяется способностью экономических агентов генерировать и использовать инновации, что является составной частью технологических трансферов, в том числе международных. Ранее нами было определено, что «без научно обоснованной и последовательной государственной политики по участию в международных технологических трансферах Республика Беларусь и Российская Федерация не смогут обеспечить высокий уровень благосостояния за счет модернизации народного хозяйства на основе новейших технологиий» [1, с. 90].

* Работа подготовлена в рамках выполнения гранта БРФФИ № Г16Р-002 от 29.04.2016 г. «Трансфер технологий в ЕАЭС в контексте формирования устойчивого экономического роста инновационного типа в Беларуси и России» 
Особый интерес в исследовании технологических трансферов с участием нашей страны представляет изучение тенденций их развития в рамках ЕАЭС.

\section{РЕЗУЛЬТАТЫ И ИХ ОБСУЖДЕНИЕ}

Сокращение технологических трансферов в ЕАЭС возможно как за счет возрастающей конкуренции между странами участницами ЕАЭС, так и в результате транзитивного характера экономик этих стран. С. Ю. Солодовников и Ю. В. Мелешко справедливо отмечают по поводу последнего: «Экономическая интеграция стран с транзитивной экономикой имеет свои особенности, что предопределяется их феноменологической природой» [2, с. 124] В результате неустойчивого (переходного) характера стран с транзитивной экономикой значительно возрастает вариативность их развития, а значит для сохранения позитивных тенденций требуются дополнительные усилия, в том числе и по поддержанию баланса экономических интересов и по сокращению дополнительных трансакционных издержек.

Позитивные тенденции в сфере технологических трансферов между странамиучастницами ЕАЭС обусловлены схожестью их экономических интересов (при этом экономические интересы отдельных хозяйствующих интересов могут противоречить экономической интеграции в рамках ЕАЭС), во многом обусловленное общностью исторической судьбы, схожестью технико-технологической основы экономики и необходимостью осуществлять четвертую промышленную революцию в условиях усиления нестабильности мировой экономики. Как отмечается в экономической литературе по этому поводу: «по мере усиления глобализации и, соответственно, ужесточения конкурентной борьбы на мировых рынках товаров и услуг роль экономической интеграции возрастает. Чем больше доля интеграционного объединения в мировом товарообороте, тем более эффективно он может решать поставленные перед ним задачи [2, с. 126].

Нестабильность международных экономических отношений и усиливающееся разнообразие бытийных форм хозяйствования в мировой экономике добавляют еще одну сложность при прогнозировании тенденций развития технологических трансферов в ЕАЭС - гносеологически-терминологическую. «В настоящее время в различного рода литературных источниках и электронных СМИ происходит лавинообразный рост диаметрально противоположных суждений как о перспективах развития мировой и национальных экономик, так и о том, какие формы хозяйственного регулирования экономически эффективны, - подчеркивают белорусские экономисты. - В результате терминологической путаницы, отсутствия категориальной определенности, в последние десятилетия в мире наблюдается увеличение отрыва экономических практик от их теоретического осмысления» [3].

Усиление интеграции в ЕАЭС «будет вести к росту экономической конкурентоспособности стран-участниц, только при условии положительного синергетического влияния на этот процессе факторов его обуславливающих за счет, во-первых, снижения социальных, политических и экономических рисков (внешних шоков), возникающих в результате усиления глобальной политэкономической нестабильности, расширения феномена глобальных финансов и растущего применения на международной арене информационного оружия как способа разрушения экономик стран-конкурентов и, вовторых, повышающих технологический, социальный, экономический, институциональный, культурный потенциалы и увеличивающих внутреннее потребление, которые выступают объективной базой роста конкурентоспособности стран-участниц» [4].

Поскольку «экономический рост в России и Беларуси будет ростом в первую очередь реального сектора экономики» [5], то и развитие технологических трансферов 
в ЕАЭС сегодня должно быть направлено в первую очередь на модернизацию реального сектора экономики Беларуси, России и других странах участницах союза. Еще в «...рамках таможенного союза (Беларуси, России и Казахстана - примечание авторов) была поставлена задача проведения технологической и институциональной модернизации национальных экономик, что в условиях возрастания глобальной конкуренции, возможно только объединившись» [2]. Поэтому главной задачей Евразийской экономической комиссии в сфере промышленности с момента ее возникновения (2012 г.) стала разработка мероприятий по усилению промышленной кооперации Беларуси, России и Казахстана, координация национальных промышленных политик с перспективой выхода на проведение согласованной промышленной политики.

Поскольку для развития конкурентных преимуществ национальных промышленных комплексов стран-участниц ЕАЭС «необходимо наличие соответствующей экономической стратегии на государственном уровне» [4] 31.05.2013 г. Решением Высшего Евразийского экономического совета № 40, определены основные направления координации национальных промышленных политик Беларуси, России и Казахстана, в том числе приоритетные для промышленного сотрудничества отрасли. «Дальнейший процесс развивался в рамках разработки проекта Договора о Евразийском экономическом союзе. Указанный кодификационный акт был расширен статьей о промышленной политике и сотрудничестве (статья 92).

Это позволило активизировать взаимодействие со Сторонами по подготовке стратегического документа по основным направлениям промышленного сотрудничества в Союзе на ближайшие 5 лет» [6]. Статьей 92 предусмотрены, во-первых, конкретные механизмы и инструменты (создание технологических платформ, инжиниринговых центров, сети трансфера технологий, систем промышленной кооперации и субконтрактации) и, во-вторых возможность разрабатывать и принимать решения, направленные на сокращение барьеров во взаимной торговле промышленными товарами, а также на реализацию конкретных мер по углублению кооперации в приоритетных отраслях [6].

Как известно, на уровне национальной экономики «...Проблема преимущественно инновационного развития страны не сводится только к развитию фундаментальной и прикладной науки, отвечающей уровню современного развития человеческой цивилизации и возникающим глобальным вызовам: это условие необходимое, но не достаточное. Решение вышеназванной проблемы <...> невозможно без формирования социально-экономических институциональных механизмов эффективного распределения новых знаний и технологий по всей территории государства. Без преимущественно инновационного развития регионов невозможно устойчивое развитие страны. В противном случае, в любом государстве будет увеличиваться количество проблемных регионов, усиливаться социальное неравенство и сокращаться количество социального капитала, накапливаемого на уровне общества» [7]. То же самое можно отнести и к ЕАЭС - без формирования социально-экономических институциональных механизмов эффективного распределение новых знаний и технологий по всей территории ЕАЭС невозможно решить проблему преимущественно инновационного развития этого союза. Поэтому в Договоре о ЕАЭС был закреплен «важнейший принцип - промышленная политика является основным ориентиром при разработке и реализации торговой, таможенно-тарифной, конкурентной политик, а также политик в области государственных закупок, технического регулирования, развития предпринимательской деятельности, транспорта и инфраструктуры» [6].

Для повышения стимулов участия предприятий стран-участниц ЕАЭС в промышленной кооперации в рамках ЕАЭС в Договор о ЕАЭС была внесена норма о взаимном признании осуществления технологических операций при принятии решения 
о предоставлении специфических субсидий. Следующим этапом развития интеграции в сфере промышленности в этом союзе стало принятие в сентябре 2015 года главами правительств Основных направлений промышленного сотрудничества в рамках ЕАЭС (ОНПС), которые были направлены на углубление кооперационного сотрудничества, проведение модернизации действующих производств и создание новых инновационных секторов промышленности, освоение новых видов конкурентоспособной экспортоориентированной продукции. Стороны договорились о формировании новой инновационной экономики путем развития сотрудничества в научно-технической и инновационной сферах, создания деловой и научной инфраструктуры [6].

17.03.2016 г. на заседании Совета Евразийской экономической комиссии были рассмотрены важные вопросы в сферах интеграции и макроэкономики, торговли, экономики и финансовой политики, промышленности и агропромышленного комплекса, технического регулирования, внутренних рынков, информатизации и информационнокоммуникационных технологий и утвержден План разработки актов и мероприятий по реализации Основных направлений промышленного сотрудничества в рамках Евразийского экономического союза (ОНПС ЕАЭС). В плане были предусмотрены действия стран-участниц ЕАЭС и Комиссии по расширению промышленного сотрудничества в рамках ЕАЭС. Совет ЕЭК также одобрил проект Положения о формировании и функционировании евразийских технологических платформ [8].

Таким образом, налицо преобладание положительных тенденций в развитии технологических трансфертов в ЕАЭС.

\section{ВЫВОДЫ}

На основании проведенного исследования можно констатировать, что на развитие технологических трансферов в ЕАЭС сегодня оказывают влияние как позитивные, так и негативные факторы. В результате их наложения тенденции этих трансферов будут носить внутренне противоречивый характер. Возможно и усиление, и ослабление технологических трансферов между странами-участницами ЕАЭС. Проведенный анализ позволил заключить, что в настоящее время преобладают положительные тенденции в развитии технологических трансфертов в ЕАЭС.

\section{СПИСОК ИСПОЛЬЗОВАННЫХ ИСТОЧНИКОВ}

1. Клименко, В. А. Развитие теоретических основ трансфера технологий в контексте перехода к устойчивому экономическому росту в Республике Беларусь и Российской Федерации / В. А. Клименко, В. Л. Гурский, Т. В. Сергиевич, Т. С. Лыткина // Корпоративное управление и инновационное развитие экономики Севера: Вестник Научно-исследовательского центра корпоративного права, управления и венчурного инвестирования Сыктывкарского государственного университета. - 2017. - № 2. - С. 85-91.

2. Солодовников, С. Ю., Мелешко, Ю. В. Евразийская экономическая интеграция // Весці НАН Беларусі, 2016. № 3. С.121-126. - С. 124.

3. Солодовников, С. Ю. Теоретико-методологические основы исследования взаимосвязи теории трудовой мотивации и динамики трудовых отношений / С. Ю. Солодовников, Т. В. Сергиевич // Вестн. Полоц. гос. ун-та. Cер. D, Экон. и юрид. науки. 2016. - № 5. - С. 12-16. - С. 14.

4. Солодовников, С. Ю., Иванова, Т. В. Влияние расширения Таможенного союза на экономическую конкурентоспособность Беларуси и Армении// Экономическая наука сегодня, 2016 - Выпуск 4. - С. 189. 
5. Солодовников, С. Ю. Занятость и создание социально-научного сообщества в условиях модернизации транзитивной экономики: на примере Республики Беларусь // Вестник Полоцкого государственного университета. Серия D: Экономические и юридические науки. 2015. № 6. С 2-9. - С.7

6. История вопроса по подготовке и реализации Основных направлений промышленного сотрудничества в рамках Евразийского экономического союза [Электронный ресурс]. - Режим доступа: http://www.eurasiancommission.org/ru/act/prom_i_agroprom/ dep_prom/Pages $/ \%$ D0 $\% 9$ E\%D0\%B1\%D1\%89\%D0\%B8\%D0\%B5-\%D1\%81\%D0\%B2\%D0\% B5\%D0\%B4\%D0\%B5\%D0\%BD\%D0\%B8\%D1\%8F-\%D0\%BF - Дата доступа: 04.05.2017 г.

7. Солодовников, С. Ю. Перспективы и механизмы развития и капитализации социального потенциала Республики Беларусь // Экономическая наука сегодня, 2013 Выпуск 1. - С. 5-33.

8. Совет ЕЭК утвердил План по реализации Основных направлений промышленного сотрудничества в ЕАЭС и решил создать Рабочую группу по формированию цифровой повестки Союза [Электронный ресурс]. - Режим доступа: http://www.eurasian commission.org/ru/nae/news/Pages/18-03-2016-6.aspx. - Дата доступа: 02.05.2017.

\section{REFERENCES}

1. Klimenko, V. A. Razvitiye teoreticheskikh osnov transfera tekhnologii? v kontekste perekhoda $\mathrm{k}$ ustoychivomu ekonomicheskomu rostu $\mathrm{v}$ Respublike Belarus i Rossiyskoy Federatsii / V. A. Klimenko, V. L. Gurskiy, T. V. Sergiyevich, T. S. Lytkina // Korporativnoye upravleniye i innovatsionnoye razvitiye ekonomiki Severa: Vestnik Nauchnoissledovatelskogo tsentra korporativnogo prava. upravleniya i venchurnogo investirovaniya Syktyvkarskogo gosudarstvennogo universiteta. - 2017. - № 2. - S. 85-91.

2. Solodovnikov, S. Yu.. Meleshko, Yu. V. Evraziyskaya ekonomicheskaya integratsiya // Vestsi NAN Belarusi. 2016. № 3. S.121-126. - S. 124.

3. Solodovnikov, S. Yu. Teoretiko-metodologicheskiye osnovy issledovaniya vzaimosvyazi teorii trudovoy motivatsii i dinamiki trudovykh otnosheniy / S. Yu. Solodovnikov. T. V. Sergiyevich // Vestn. Polots. gos. un-ta. Ser. D. Ekon. i yurid. nauki. - 2016. - № 5. - S. 12-16. - S. 14.

4. Solodovnikov, S. Yu.. Ivanova T. V. Vliyaniye rasshireniya Tamozhennogo soyuza na ekonomicheskuyu konkurentosposobnost Belarusi i Armenii// Ekonomicheskaya nauka segodnya. 2016 - Vypusk 4. - S. 189.

5. Solodovnikov, S. Yu. Zanyatost i sozdaniye sotsialno-nauchnogo soobshchestva v usloviyakh modernizatsii tranzitivnoy ekonomiki: na primere Respubliki Belarus // Vestnik Polotskogo gosudarstvennogo universiteta. Seriya D: Ekonomicheskiye i yuri-dicheskiye nauki. 2015. № 6. S 2-9. - S.7

6. Istoriya voprosa po podgotovke i realizatsii Osnovnykh napravleniy promyshlennogo sotrudnichestva $\mathrm{v}$ ramkakh Evraziyskogo ekonomicheskogo soyuza [Elektronnyy resurs]. - Rezhim dostupa: http://www.eurasiancommission.org/ru/act/prom_i_agro prom/dep prom/Pages/\%D0\%9E\%D0\%B1\%D1\%89\%D0\%B8\%D0\%B5-\%D1\%81\%D0 $\% \mathrm{~B} 2 \%$ D0 \%B5\%D0\%B4\%D0\%B5\%D0\%BD\%D0\%B8\%D1\%8F-\%D0\%BF - Data dostupa 04.05.2017g.

7. Solodovnikov, S. Yu. Perspektivy i mekhanizmy razvitiya i kapitalizatsii sotsialnogo potentsiala Respubliki Belarus // Ekonomicheskaya nauka segodnya. 2013 - Vypusk 1. - S. 5-33.

8. Sovet EEK utverdil Plan po realizatsii Osnovnykh napravleniy promysh-lennogo sotrudnichestva $\mathrm{v}$ EAES i reshil sozdat Rabochuyu gruppu po formirovaniyu tsifrovoy 
povestki Soyuza. [Elektronnyy resurs]. - Rezhim dostupa: http://www.eurasiancommission. org/ru/nae/news/Pages/18-03-2016-6.aspx. - Data dostupa: 02.05.2017.

Статья поступила в редакиию 15 октября 2017 года. 